Revista Iberoamericana, Vol. LXXIV, Núm. 222, Enero-Marzo 2008, 179-191

\title{
"UM LIVRO MAIOR DO QUE A GENTE": SUGESTÕES PARA UMA RELEITURA DOS PREFÁCIOS DE TUTAMÉIA DE JOÃO GUIMARÃES ROSA
}

\author{
POR \\ Pedro Pereira \\ The University of Chicago
}

\begin{abstract}
For now we see through a glass, darkly; but then face to face: now I know in part; but then shall I know even as also I am known.
\end{abstract}

S. Paulo (Corinthians I, XIII, 12)

\begin{abstract}
Antes de ter um conteúdo filosófico, antes de constituir ou de conter esta ou aquela “tese,” a experiência literária, a escrita ou a leitura [a escrita $e$ a leitura], é uma experiência "filosófica" neutralizada ou neutralizante na medida em que permite pensar a tese; é uma experiência não tética da tese, da convicção, da posição, da ingenuidade[... $]^{1}$
\end{abstract}

J. Derrida, "This Strange Institution Called Literature"

A versão joco-séria da passagem de S. Paulo citada em epígrafe, pode encontrar-se em "Aletria e Hermenêutica”, o primeiro dos quatro prefácios que Guimarães Rosa compilou em Tutaméia-Terceiras Estórias: “A vida também é para ser lida. Não literalmente, mas em seu supra-senso. E a gente por enquanto, só lê por linhas tortas” (4). ${ }^{2}$ Esta espécie de aforismo é introduzida no texto do prefácio como complemento à explicação proposta para as "anedotas de abstracção”, constituindo estas como que o modelo para o conceito rosiano de "estória", e cuja definição parece ser o objectivo deste texto com que se inicia a colectânea. Imediatamente a seguir, surge uma justificação, ou, se se preferir, uma autorização, uma prova da validade de tal aforismo: "Está-se a achar que se ri. Veja-se Platão, que nos dá o 'Mito da Caverna'”. Podemos conjeturar se S. Paulo seria ou não lido em Platão, mas sabemos com segurança que a filosofia grega e o platonismo em particular fizeram parte da linguagem que falam os primeiros teólogos do cristianismo, por via das recorrentes assimilações, inversões, traduções que estes operam a partir dos textos que a eles chegam da Antiguidade. A questão que aqui subrepticiamente começa a insinuar-se

\footnotetext{
${ }^{1}$ A tradução desta passagem, bem como das que se seguem desta entrevista de Jacques Derrida, é da minha responsabilidade.

${ }^{2}$ Sublinhado meu. Esta passagem é aquela que mais claramente coloca em evidência a intenção jocoséria de Guimarães Rosa em relação à famosa expressão paulina "through a glass, darkly".
} 
é a seguinte: como encarar a intrusão de uma dimensão de seriedade - denotada pela citação, pelo recurso à autoridade - num texto que aparentemente procura interrogar o humor e a comicidade? Esta questão desfia-se, como um rosário, em outras quantas: Como entender o trânsito quase imediato que no prefácio se opera a partir da linguagem do humorismo em direcção à linguagem da alegoria? E por que razão se coloca tal trânsito sob a égide de Platão e do discurso espeleológico por ele desenvolvido na célebre passagem de A República? Ao tentar entender estas questões em todo o seu alcance, iremos também e de novo deparar com uma outra ordem de questões, não menos decisivas, não menos enigmáticas: em que medida é o próprio conceito de prefácio, e com ele o conceito de livro, o alvo preferencial da alegorese humorística rosiana? Qual o papel de um tal questionamento - que se gera no seio de um conflito, de uma partilha, de um encontro tangencial entre os discursos filosófico e literário - na economia da obra de Guimarães Rosa? Abrir caminho no entendimento destas questões, que como questões restarão, é o propósito a um tempo heurístico e hermenêutico deste trabalho.

Começarei por discutir a leitura que o crítico Jon Vincent propôs deste livro seminal, e nomeadamente a visão que nela está implícita de uma relação oposicional dos discursos filosófico e literário, a qual a meu ver restringe drasticamente o potencial crítico-filosófico que assiste a linguagem ficcional de João Guimarães Rosa, ao esquecer o quão filosófica é ainda a paródia rosiana da filosofia. Em seguida, proponho uma leitura crítica do conceito de "anedota de abstração" apresentado por Rosa neste livro, sustentando que é na apresentação e elaboração de tal conceito que a questão fulcral da relação dos discursos filosófico e literário se insinua com maior premência. No seguimento desta leitura sustento que o efeito propriamente literário da anedota de abstração - partindo do princípio questionável de que a literariedade de um texto alguma vez se apresente com foros de propriedade - reside na exemplaridade de uma experiência iminentemente prática: só contando uma estória podemos saber como se conta uma estória. Por fim, procuro esclarecer o papel desempenhado na ficção rosiana, e em Tutaméia em particular, pelo conflito encenado entre as dimensões convencional e invadora do "prefácio”. Se por um lado Guimarães Rosa se serve claramente da dimensão convencional do prefácio, na medida em que publica o texto de "Aletria e Hermenêutica” apenas quando reúne em volume todas as narrativas constantes de Tutaméia, isto é, apenas quando pretende reunilas sob a égide de uma ideia ou de um projecto coerentes, por outro lado a sua escrita em Tutaméia torna patente uma dimensão como que subversiva do prefácio, em que o desvio autobiográfico e rememorador se transforma na substância mesma do escrito, quer dizer, no fio orientador da lição de escrita e de leitura que Terceiras Estórias não deixa também de constituir. Assim, procuro explicitar em que medida “Aletria e Hermenêutica” assume um estatuto de exemplaridade no volume e como se estabelecem as relações prefaciais entre este texto e os restantes textos classificados como prefácios. E termino por mostrar como a estratégia estético-teórica de Rosa consiste na rentabilização máxima da “ aporia ficcional” do prefácio ou, por outras palavras, da capitalização da indecibilidade, nos seus textos prefaciais, entre as dimensões ficcional e teórica da escrita. Uma indecidibilidade que o gesto prefacial não logra rasurar e antes contribui para adensar.

Num estudo já clássico sobre a obra de Guimarães Rosa, Jon Vincent afirma, sobre os prefácios de Tutaméia: 
The prefaces of Tutaméia are [...] precisely the opposite of philosophical treatises. Rather than attempts to employ logic and reason in the explication of an orderly system, they are statements on the randomness of all order, expositions on a reality no longer hinged to a coherent system. Given the importance of the tangential, the unexpected, and the extraterreal in earlier works, it is not surprising that the prefaces have been used by critics as a point of departure for discussing all of Guimarães Rosa's works. (111)

Se é possível concordar sem hesitação com a afirmação de que estes textos não constituem tratados filosóficos, mais difícil será aceitar, sem mais investigação, a de que eles são o oposto de um tratado filosófico. ${ }^{3}$ Ainda que correcta no seu propósito interpretativo, os termos em que está colocada esta afirmação parecem-me enfermar de uma visão muito estreita do que é filosófico e do que é literário, incorrendo no risco de deixar escapar como que por entre os dedos aquilo mesmo que os prefácios logram trazer à discussão.

Parece-me francamente redutor, por exemplo, definir o estatuto filosófico de um dado discurso pelo mero uso da lógica e da razão, como se esse uso não estivesse também em jogo em qualquer discurso literário que mereça esse nome, isto é, que faça sentido. Por outro lado, reduzir o trabalho filosófico à construção de sistemas coerentes de ideias sobre a realidade é em última análise ignorar ou passar por alto a evolução que dentro das fronteiras regionais da disciplina filosófica se verificou nos últimos 150 anos, nos quais esse modelo foi questionado, criticado, descontruído. Mais ainda, e isto é talvez mais importante, a visão estreita de separação entre os discursos literário e filosófico aludida por Vincent parece-me reproduzir apenas um conceito clássico, um estereótipo filosófico de onde muito discurso crítico da literatura deriva cegamente, sem nunca questionar os seus próprios pressupostos. Com efeito, de Platão a Hegel, pelo menos, a filosofia sempre procurou constituir-se como uma linguagem em conflito com o poético e com o literário, ${ }^{4}$ sempre procurou relegar o literário para as "margens" do pensamento verdadeiro. Por outras palavras, o conflito que historicamente opôs filosofia e literatura foi sempre por aquela neutralizado, reduzido a dicotomias do tipo razão/imaginação ou verdade/ilusão, entre outras que traem uma mesma origem sistemática.

A necessidade de releitura dos prefácios de Tutaméia surge pois da perplexidade em relação a estas dicotomias, perplexidade esta que, sustento eu, floresce significativamente na escrita matreira de João Guimarães Rosa. Esta releitura tem também de lidar com o facto de que estes prefácios, como assinala Jon Vincent, foram tradicionalmente usados pelos críticos como um ponto de partida para a discussão da totalidade da obra de Guimarães Rosa. Mas se estes se limitaram em parte a reproduzir nas suas leituras a mesma estratégia alegórica que atribuem à escrita do autor mineiro, é possível no entanto ler os prefácios

\footnotetext{
${ }^{3}$ Na verdade, e se não corrêssemos o risco da digressão, poderíamos aqui produtivamente perguntar: o que é o oposto de um tratado filosófico? É esse um conceito logicamente sustentável, sobretudo no âmbito de um entendimento sistemático e não problemático da filosofia, como parece ser o de Jon Vincent?

${ }^{4}$ Sobre as diferenças entre poesia e literatura, veja-se, entre outras fontes possíveis, a entrevista de Derrida de onde extraí a segunda epígrafe para este texto, "This Strange Institution Called Literature".
} 
enquanto uma espécie de corpus autónomo sem exercer violência em relação ao projecto do livro em geral. Sem avançar para já o que isto possa querer dizer quanto ao estatuto genérico e literário da forma prefácio, parece-me no entanto essencial atentar no seguinte: os prefácios de Tutaméia, cuja publicação antecede de pouco a morte do autor, são na verdade posfácios rememorativos da totalidade da obra e do percurso biográfico e artístico de Guimarães Rosa, em que a relação do biográfico e do artístico deve ser entendida como uma relação de contiguidade e complementaridade. Mas, como ressalva, é preciso sublinhar que não devem estes textos ser encarados como textos pedagógicos, como uma espécie de ponto de chegada - suplemento ou apêndice - em que, através da explicação, o autor finalmente tomaria posse, pelo conhecimento rememorativo, do seu destino de criador.

Como textos eminentemente autobiográficos, ${ }^{5}$ os prefácios de Tutaméia constituem antes um aprofundamento desse destino, um relançamento da obra, um acrescento que complica a cena sem a resolver, uma digressão suplementar e um abismo que, ao alojar-

\footnotetext{
${ }^{5}$ Autobiográficos não apenas pelo facto de em “A Escova e a Dúvida” Rosa aludir a vários passos da sua formação como escritor, mas também porque, como veremos, os prefácios são textos em que o autor se reencontra com as premissas do seu próprio projecto estético-literário - o qual a mais de um título se confunde com o seu trajecto biográfico -, com a dificuldade e com o ciclópico da tarefa de narrar o real, entendida esta palavra no sentido rosiano, de cruzamento entre o possível e o impossível. O real, aquilo que acontece, é em Rosa também o desejo de que aquilo que não acontece deveria acontecer. Os prefácios de Tutaméia, bem como a obra de Rosa em geral, constituem entre outras coisas a narrativa da descoberta de que as formas discursivas de que dispomos são muito mais pobres do que aquilo que acontece. Uma noção muito semelhante de autobiografia encontra-se em Derrida, e nomeadamente na entrevista intitulada "This Strange Institution Called Literature" da qual foi extraída a epígrafe deste trabalho. Aí podemos ler: "Sem dúvida hesitei entre a filosofia e a literatura, sem nunca desisitir de nenhuma, talvez buscando obscuramente um lugar a partir de onde a história desta fronteira poderia ser pensada ou até deslocada - na escrita em si mesma e não apenas na reflexão teórica e/ou histórica. E como aquilo que me interessa hoje não pode estritamente ser chamado literatura nem filosofia, divirto-me com a ideia de que o meu desejo adolescente, chamemos-lhe assim, acabaria por me direccionar para algo na escrita que não se confunde nem com uma nem com a outra. O que é isso, então? 'Autobiografia' é talvez o nome menos inadequado, porque permanece para mim o mais enigmático, o mais aberto, mesmo hoje” (35). Mais adiante: "Neste momento, aqui, estou a tentar, num modo que seria comummente chamado 'autobiográfico', recordar o que aconteceu quando o desejo de comunicar me surgiu, de uma forma que era tão obscura quanto compulsiva, autoritária e impotente. [...] Ainda hoje resta em mim um desejo obsessivo de salvaguardar numa inscrição ininterrupta, na forma de uma memória, aquilo que acontece - ou deixa de acontecer. [...] Acabo de dizer 'deixa de acontecer' [...] de forma a marcar o facto de que aquilo que acontece - por outras palavras, o evento único cujo rastro gostaríamos de manter vivo - é também o desejo mesmo de que aquilo que não acontece deveria acontecer, e constitui já a 'estória' em que o evento desde logo atravessa em si mesmo o arquivo do 'real' e o arquivo da 'ficção'. Já aqui teríamos de enfrentar vários problemas ao não assinalarmos mas antes separarmos narrativa histórica, ficção literária e reflexão filosófica” (35). Esta longa citação, em que os sublinhados são da minha responsabilidade, assinala aqui a necessidade crucial de uma reflexão mais demorada, posto que impossível no contexto deste trabalho, sobre o motivo da autobiografia e as diversas complicações da sua manifestação num contexto ficcional como é o de Tutaméia. Fica no entanto sugerida a direcção que deve tomar a investigação futura, e a atenção que devem merecer as dimensões do desejo, do real e da ficção na configuração de uma teoria rosiana da "estória".
} 
se no espelho em que o autor se mira, abre a sua obra ao infinito. Mas se esta abertura sugere uma noção de incompletude da obra, esta incompletude não deve todavia ser interpretada num sentido de carência ou de negatividade. Como o próprio narrador reconhece, de resto, quando em “A Escova e a Dúvida” desabafa: “Um escrito, será que basta? Meu duvidar é uma petição de mais certeza” (149). Mais certeza, ou, diríamos nós, mais escrita. Neste sentido, julgo ser importante chamar a atenção para o reparo que Luiz Valente endereça a Stephanie Merrim num artigo intitulado "Fiction and the Reader: The Prefaces of Tutaméia”, e com cujo teor concordo: “My analysis differs from Merrim’s in at least one point. While she believes that the 'ideal writing' conceived by Tio Cândido might 'satisfy the readers' and the writer's quest for greater certainty in the world', I do not see any possibility for such satisfaction. On the contrary, I prefer to stress the sense of perennial search and of desire never completely fulfilled, which I consider to be essential elements in Guimarães Rosa's worldview” (357).

“Aletria e Hermenêutica” é, segundo Vera Novis, o único dos prefácios que parece ter sido escrito com o intuito de prefaciar, no sentido tradicional do termo, o conjunto de contos reunidos em Tutaméia, visto estar inédito até à data de publicação do volume. À primeira vista desconcertante, o título do prefácio torna-se mais compreensível com a leitura do texto: trata-se de contrapor, a uma noção fechada do texto literário e da sua interpretação, a hermenêutica ${ }^{6}$ como uma prática da escrita e da leitura em que o que está doravante em jogo não é tanto o conhecimento enciclopédico do leitor letrado, bem como a sua capacidade de desvendar a origem do sentido do texto, mas antes a audácia de operar, por via daquilo a que Guimarães Rosa chama a abstracção, um regresso a uma visão da realidade em que já não há lugar para a distinção entre senso/contra-senso, uma visão que "reflete por um triz a coerência do mistério geral, que nos envolve e cria” (4). A aletria, ou a-letria, no sentido rosiano de inversão da letra na escrita, é afinal a prática da estória, tal como a hermenêutica, conhecimento seguro da realidade e da verdade do texto, é a prática da história. ${ }^{7}$

É no momento em que explica a lógica das “anedotas de abstracção” que Guimarães Rosa recorre a Platão e à sua célebre alegoria da caverna, com o intuito de justificar a passagem que a sua própria escrita opera entre humorismo e alegoria. O efeito observado de uma anedota de abstracção ultrapassa a dimensão meramente cómica e assegura afinal a sobrevivência da anedota nos domínios do poético e da transcendência. E que efeito é esse? O de "escanchar os planos da lógica, propondo-nos realidade superior e dimensões para mágicos novos sistemas de pensamento” (3). Seguem-se quarenta e oito exemplos de tais anedotas, a que na verdade devemos somar as explicações que Rosa adianta para algumas delas (já que tais explicações são outras versões das mesmas anedotas), ${ }^{8}$ bem como os vinte e um corolários com que finaliza o texto.

${ }^{6}$ Entendida no sentido que a palavra assumia antes de autores como Heidegger, Gadamer e Paul Ricoeur a terem reformulado ontologicamente, num sentido a que não podemos aqui dar a atenção devida.

${ }^{7}$ Explicações satisfatórias deste título encontram-se no artigo já citado de Luiz Valente (354) e também em José Maria Martins, Guimarães Rosa-O Alquimista do Coração (18-19).

${ }^{8} \mathrm{E}$ aqui é o lugar de de novo interpelar Jon Vincent e perguntarmo-nos: o que dizer deste trânsito, como explicar a passagem da anedota mesma à sua explicação séria, dentro da estrita dicotomia 
“Aletria e Hermenêutica” começa então por ser a estória de como alcançar os tais “mágicos novos sistemas de pensamento”, composta de todas essas minúsculas estórias de iluminação, inventadas pelo narrador ou por ele recuperadas da sabedoria popular do sertão mineiro. Mas é também a prática, pela escrita, desse caminho de iluminação, e não apenas a sua alegoria encantada, a sua douta pedagogia. E só porque é uma estória, é que “Aletria e Hermenêutica” pode constituir também um prefácio de estórias: só pela prática se pode mostrar a prática, residindo aqui a raiz da experiência rosiana da escrita. Mas é prudente não nos adiantarmos nas nossas conclusões. Devemos demorar-nos um pouco mais neste texto, e, tanto quanto possível, experimentar todas as suas nuances.

Uma delas é a de que esta é também uma estória de partilha, económica, entre os discursos da literatura e da filosofia. Não apenas porque Guimarães Rosa apela à autoridade filosófica de Platão para justificar o seu recurso à anedota de abstracção. De resto, está ainda por determinar até que ponto deve Platão à poesia e à literatura os mitos de que se serviu para explicar os seus conceitos; não nos podemos esquecer que, segundo a lenda, para poder ser admitido como discípulo de Sócrates, Platão teve de destruir todas as tragédias compostas durante a juventude. ${ }^{9}$ Mas esses escritos, essas estórias deixaram os seus restos, os seus vestígios insidiosos no corpo mesmo daquilo que se constituiu na e pela sua escrita como o saber verdadeiro, e a tal ponto que não podemos, sem correr um risco insensato, erradicar essas narrativas ficcionais da narrativa da verdade, sem nesse mesmo gesto mutilar esse como que corpo excelso. Quando Rosa cita Platão, cita o filósofo ou o poeta? Deveríamos por uma vez admitir que não cita nenhum, se não cita os dois, isto é, se não cita o polílogo que Platão não conseguiu nunca neutralizar. Um polílogo, ou uma voz múltipla como aquela “voz do Sertão” que também fala em Guimarães Rosa, quer dizer, em Riobaldo, em Diadorim, em Hermógenes, em Ladislau...

O estatuto filosófico de um texto não advém portanto do recurso a "conceitos filosóficos" ou a "teses filosóficas”, como um lugar comum inquestionado de certo discurso crítico da literatura quer fazer crer; não existe tal coisa como um "conceito filosófico": o filosófico não está no texto como uma essência cristalizada, ele é antes uma determinada orientação que se dá a uma cadeia de conceitos. Mas um texto tem sempre a capacidade matreira de se escapar, ao mesmo tempo que faz parte, dessa cadeia. A filosofia nasce desde logo, como Sócrates ensinava, da arte do espanto perante a realidade. E que mais é senão espanto, na mais fecunda dimensão do termo, uma adivinha como esta: “O

filosofia/literatura com que Jon Vincent se propôs analisar Tutaméia? E que dizer destes "mágicos novos sistemas de pensamento" e da sua filiação sem dúvida ainda filosófica ou em todo o caso não o oposto de uma tal filiação?

${ }^{9}$ Sabemos também, através da releitura de A República, que há mais em jogo neste episódio do que uma mera estória de iconoclasmo adolescente. Toda a teoria da cidade ideal (e, por conseguinte, da cidadania ideal) desenvolvida por Platão em esse e em outros diálogos, segundo a qual os poetas não têm aí lugar, não tem direito de cidadania, configura não apenas o destino cultural do Ocidente, através da separação conflitual entre filosofia e poesia, entre a boa e a má mimesis, mas também, numa medida que só hoje podemos começar a entender, o destino político da cultura ocidental, com as suas instituições, os seus interditos e as suas liberdades vigiadas. Não teremos lido Tutaméia se não lermos esse livro também como uma certa leitura transformante desse destino, dessas instituições e desses interditos. 
copo com água pela metade: está meio cheio, ou meio vazio?” (12). A resposta nunca poderá advir da lógica, tanto quanto do desejo do respondente.

Mas a filosofia insinua-se também na paródia filosófica que Guimarães Rosa encena em “Aletria e Hermenêutica”. Todo o prefácio é construído em torno de uma demonstração "aletrada" do uso económico das anedotas de abstracção, e a filosofia surge sempre no texto em tom jocoso, um tom que se mantém até ao final quando, depois de enunciar os corolários finais da sua demonstração insólita, o narrador termina o texto com a célebre sentença da escolástica medieval, “Quod erat demonstrandum” (12). Sabemos pelo menos desde Platão e Aristófanes que aquilo que fala na sátira da filosofia é ainda e sempre a mesma filosofia como máscara de si própria. Quando em “Aletria e Hermenêutica” o narrador recorre ao humor metafísico, fá-lo apenas com intuitos gratuitos? ${ }^{10}$ Ou será que, através desse humor, que se transmite ao texto de "Nós, os tremulentos”, esse narrador trickster estará ainda a aludir, muito economicamente, a um certo conhecimento alcançável através da prática da estória, ou prática da escrita? Esta questão pode ser melhor elucidada se, at ítulo de exemplo, recorrermos a uma alegoria que Blanchot tece em O Livro Por Vir quando procura iluminar a relação entre as ideias de finito, infinito e cegueira na obra de Borges. Se aceitarmos que Borges produziu uma obra em que as questões levantadas pelos prefácios de Tutaméia são cíclicamente afloradas, senão mesmo obsessivamente assediadas, então o paralelo com Guimarães Rosa não apenas se justifica aqui como espero, mas pode também investir-se de uma virtude heurística. Por outro lado, Blanchot oferece-nos o exemplo de uma escrita em que a evidência crítica é sempre indestrinçável da dimensão poética da linguagem, razão pela qual se justifica a meu ver a longa extensão da passagem que se segue:

A verdade da literatura estaria no erro do finito. O mundo em que vivemos e tal como vivemos é, felizmente, delimitado. Bastam-nos alguns passos para sairmos do nosso quarto, alguns anos para sairmos da nossa vida. Mas suponhamos que, neste estreito espaço, subitamente obscuro, subitamente cegos, nos descaminhávamos. Suponhamos que o deserto geográfico se tornava o deserto bíblico: já não é de quatro passos, já não é de onze dias que precisamos para o atravessar, mas do tempo de duas gerações, mas de toda a história de toda a humanidade, e talvez ainda mais, para o homem medido e de medida, o quarto, o deserto e o mundo são lugares estritamente determinados. Para o homem desértico e labiríntico, votado ao erro de um empreendimento necessariamente um pouco mais longo que a sua vida, o mesmo espaço será verdadeiramente infinito, ainda que saiba que o não é, e tanto mais quanto melhor o souber. (103)

Substituindo a palavra deserto por sertão, temos uma indicação do quanto esta apreciação se aplica também ao Guimarães Rosa de Tutaméia. E a locução por mim sublinhada no final da passagem sugere-nos uma possibilidade de leitura em que a ordem do conhecimento não é por si só capaz de abolir a ordem da ficção, logrando ao invés alimentá-la, reorientando assim a dicotomia verdade/ficção no sentido de uma complementaridade votada ao infinito.

${ }^{10}$ No sentido estrito do termo, e não naquele que Rosa recupera da etimologia. 
Isto é, uma tal reorientação sugere-nos por sua vez a existência de uma economia da verdade subjacente em Tutaméia, assim como na obra de Guimarães Rosa globalmente considerada. E mais sugere que uma tal economia partilha em igual medida dos recursos da filosofia e dos da literatura. Não será o efeito propriamente literário destas peças alcançado justamente através da manutenção da indecidibilidade entre filosofia e literatura? Insistamos. Se, por um lado, deparamos em “Aletria e Hermenêutica” com uma desconfiança, por via da sátira e da paródia, em relação a uma certa maneira de encarar a filosofia no seu destino histórico, ${ }^{11}$ não implicará isso, por outro lado, a assunção de uma outra verdade que, ainda que seja a verdade da ficção, é ainda filosoficamente condicionada? É verdade que Guimarães Rosa não pretendia desistir deste mundo e emigrar para o mundo platónico das ideias; mais do que literário ou filosófico, esse impulso seria religioso. De resto muitos dos críticos que se têm referido ao "platonismo" de Rosa - e em toda a precisão deveriam antes referir um neo-platonismo - esquecem que o mundo dos arquétipos apenas tem interesse no seu choque com o mundo do quotidiano, com o mundo da lógica. $\mathrm{O}$ conhecimento que lhe interessa é aquele que resulta desse choque. Esse conhecimento que constituiria afinal “o leite que a vaca não prometeu” (3-4), mas conhecimento ainda.

Talvez a partir de agora possamos começar a tentar entender o que está em causa nos prefácios de Tutaméia. Se seria legítimo experimentar alguma perplexidade pelo facto de depararmos, ao ler este livro, com quatro prefácios e não apenas um, e até por isso sermos levados a pensar, como vários o fizeram, que Guimarães Rosa estaria apenas a pregar uma partida aos críticos, ${ }^{12}$ dispomos no entanto agora de alguns elementos para propor uma interpretação diferente. Antes de avançar com ela, no entanto, cumpre advertir que não obstante o carácter de insólito associado à forma como esses textos se apresentam no corpo do livro, “Aletria e Hermenêutica” é ainda um prefácio no sentido convencional do termo, isto é, um texto que apresenta ao leitor o texto que se lhe segue na ordem do livro. Porque aquilo que se deixa dizer nesse texto é não só crucial para a compreensão dos restantes prefácios, como também para a compreensão do livro na sua globalidade, e até da globalidade da obra de Guimarães Rosa. E até também, como veremos de seguida, fulcral para a compreensão do motivo pelo qual o narrador pretende que os mesmos prefácios sejam lidos não apenas como parte integrante do livro, mas também como um corpus à parte, fora do livro ou, mais precisamente, como encenação da possibilidade de um "forado-livro”. Vejamos como se relaciona o primeiro com cada um dos restantes três prefácios.

"Nós os tremulentos" retoma a questão da percepção da realidade já ensaiada em “Aletria e Hermenêutica”, desta vez através da narrativa do dia-a-dia de um bêbedo e da sua visão “distorcida” das coisas. Uma vez mais, são as situações a uma primeira leitura apenas cómicas que despertam a atenção para a existência de uma outra dimensão da

${ }^{11} \mathrm{E}$ também a solicitação de uma outra verdade, a que o narrador refere como a "do mistério geral, que nos envolve e cria”, isto é, a verdade tangencialmente platónica que corrigiria o nosso olhar para as coisas.

${ }^{12}$ É o caso de Paulo Ronai, no seu artigo sobre os prefácios, publicado em apêndice à edição de Tutaméia de que tenho vindo a servir-me: “Eles’ eram evidentemente os críticos. Rosa, para quem escrever tinha tanto de brincar quanto de rezar, antegozava-lhes a perplexidade encontrando prazer em aumentá-la. Dir-se-ia até que neste volume quis adrede submetê-los a uma verdadeira corrida de obstáculos” (194). 
realidade que, não obstante coabitar com aquela que supostamente é a nossa de todos os dias, passa no entanto e amiúde despercebida. Escusado será acrescentar que o "estar bêbedo” é apenas a metonímia da percepção alterada sobre a qual Tutaméia não deixa de falar, do princípio ao fim. Pormenor interessante é o facto de esta narrativa se recortar sob o pano de fundo filosófico do "conflito essencial e drama talvez único" (101) de estar-nomundo.

"Hipotrélico" é uma continuação quase que lógica do primeiro prefácio: para uma prática consequente da estória, é necessário estabelecer o direito ao trabalho da língua. Trabalho esse que passa pela invenção de neologismos, tanto quanto pela reabilitação de vocábulos caídos em desuso - e que não deixam assim de constituir também neologismos de diferente categoria - que provocarão no leitor uma sensação de extranheza capaz de lhe fazer ver o avesso da língua, e de o/a fazer embarcar na tarefa propriamente literária de nomeação do impossível. Dá-se neste prefácio uma ênfase a uma performatividade que deve ser analisada à luz de uma experiência de escrita que já não consiste necessariamente num “conhecimento teórico”, mas que é antes análoga à promessa, a um acto quase que de instituição que, ao transformar a linguagem, transforma muito mais do que isso. Circula nas suas entrelinhas também uma determinada leitura das relações entre literatura e os discursos das ciências humanas, e nomeadamente o da história, na medida em que todo o acto criativo que institui uma ruptura em relação a uma tradição assume ao mesmo tempo uma responsabilidade em relação a essa tradição. Quer dizer, só através da criação e da ruptura pode uma tradição sobreviver.

Esta performatividade, esta experiência de escrita é muito mais interessante do que a mera repetição. Até porque a repetição é sempre já a alma da escrita, e uma obra que não (se) abrisse através da sua performatividade o espaço de uma diferença estaria apenas a incorrer na tautologia, na reprodução estéril. ${ }^{13}$

Outro aspecto significativo neste prefácio, e que é relativo à concepção de prefácio e de livro que Guimarães Rosa pretende colocar em prática, é o de nele o narrador levar a cabo uma espécie de inversão da normativização da língua. É interessante lembrar que com o conceito moderno de livro, surgido com o advento da imprensa e da possibilidade de reprodução virtualmente ilimitada dos textos que até então estavam confinados ao espaço das bibliotecas monacais, surge também a necessidade de normativizar as línguas nacionais, que destronam então o latim como língua exclusiva da erudição. É nesta altura que surgem as primeiras gramáticas, que espelham essa preocupação pelo uso correcto da língua. ${ }^{14}$ Há como que uma função reguladora e laicizadora introduzida pela escrita

\footnotetext{
${ }^{13} \mathrm{Na}$ entrevista que tenho vindo a citar, Derrida esclarece este ponto da seguinte maneira: Mesmo se isso não constitui um dever moral ou político (mas pode tornar-se isso), esta experiência de escrita está "sujeita" a um imperativo: o de dar espaço a eventos singulares, o de inventar algo de novo nas formas de actos de escrita que já não consistem em conhecimento teórico, em novas declarações constativas, o de entregar-se a uma performatividade poético-literária pelo menos análoga à das promessas, ordens ou actos de constituição ou legislação que não só modificam a língua ou que, ao modificarem a língua, modificam mais do que isso. O que é sempre mais interessante do que repetir (55).

${ }^{14}$ Em A Escrita do Livro, um dos poucos títulos que em Portugal surgiu sobre esta questão, Maria Augusta Babo chama a atenção para o seguinte: "Concomitantemente ao aparecimento da tipografia,
} 
tipográfica que a a-letria rosiana pretende inverter, não para preconizar um regresso ao monopólio monástico da escrita, mas antes para encenar o regresso à ficção absoluta de um antes da escrita, com o intuito de melhor fazer experimentar ao leitor a escrita como mistério.

"Sobre a Escova e a Dúvida” propõe-nos um conjunto de sete narrativas (seis mais o glossário) em que se revisitam e aprofundam todas as questões até então levantadas, com uma ênfase particular sobre a questão do duplo e com um tom conferido pelas epígrafes de Sexto Empírico nas quais se fala da "suspensão do juízo", a célebre e uma vez mais filosófica epoké que da antiguidade, passando por Montaigne e Descartes (e pelo português Francisco Sanches) irá ser exercida em tempos mais próximos dos nossos por nomes como Wittgenstein. Há ainda um registo autobiográfico evidente que perpassa todo o prefácio e se torna mais nítido na revisitação da obra levada a cabo na parte VI. É importante vincar, no entanto, que o tom conferido ao texto pelas epígrafes permanece ambíguo, e é dessa ambiguidade que poderemos extrair o sentido deste e dos restantes prefácios de Tutaméia. Tal ambiguidade resulta do facto de o narrador justapor, com intuitos paródicos, as passagens de Sexto Empírico sobre a tranquilidade que advém da prática da suspensão do juízo a uma narrativa que tem como inspiração uma experiência da intranquilidade absoluta, quer seja em relação aos actos inexplicados do quotidiano, como o de escovar os dentes em jejum, ou à estranha e perigosa empatia entre escritor e personagens narrada na parte VI. Não há tranquilidade possível na prática da escrita, ou, por outras palavras, a escrita é uma constante petição de intranquilidade.

Os quatro prefácios têm em comum o facto de serem narrativas ou de serem compostos de narrativas que se decompõem por sua vez em sub-narrativas. Devemos também levar em conta a relação que se estabelece entre os textos dos prefácios propriamente ditos e os textos das epígrafes e notas de rodapé, relação essa que - por exemplo na parte III de "Sobre a Escova e a Dúvida” - é radicalizada ao ponto de a narrativa surgir como que em continuação imediata ao texto da epígrafe, como se do mesmo texto se tratasse:

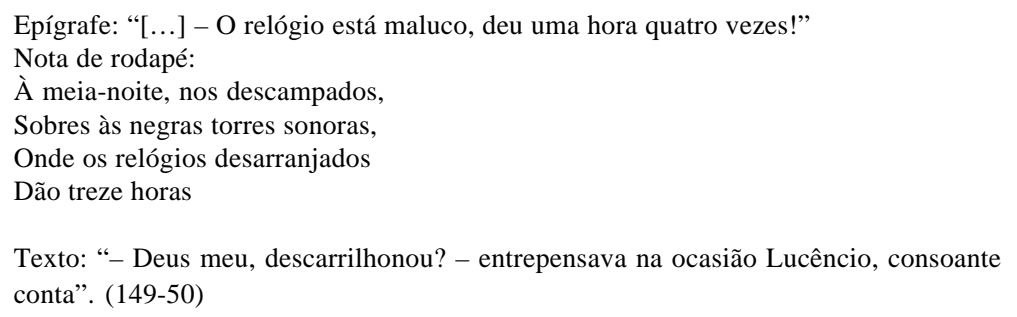

que, para além do mais, desambiguiza e fixa os textos [...] surgem as primeiras gramáticas que têm por função a homogeneização e a ortopedização das línguas. A multiplicação e difusão facilitam a passagem da caligrafia à letra impressa que, embora no início tente imitar a língua manuscrita, depressa institui os caracteres tipográficos. A imprensa exerce uma influência niveladora em todas as formas verbais e sociais, estabilizando, normalizando, regulamentando e normativizando as línguas” (23). 
O carácter de exemplaridade destes textos, que permite ao narrador propô-los como prefácios, isto é, como apresentação dos textos subsequentes, reside justamente nesse seu carácter ficcional, intratextual e intertextual. Trata-se de textos híbridos, a um tempo ficcionais, autobiográficos e teóricos, sem que nehuma das dimensões se sobreponha à outra, ou, por outras palavras, o seu equilíbrio estético-teórico apenas se mantém sob a condição de nenhuma das dimensões se sobrepor hierarquicamente às restantes.

Se a uma primeira leitura estes textos nos parecem, enquanto prefácios, pouco convencionais, dada a sua disposição no volume, é apenas porque o que está em causa, através dessa inovação performativa, é justamente a desconstrução da atitude "tética" com que se escrevem tantas vezes e convencionalmente os prefácios. Mas essa desconstrução apenas como acto de responsabilidade em relação à tradição que se desconstrói: não se trata de mero iconoclasmo cultural, ou de jogo gratuito, ainda que haja muito de jogo em Tutaméia. Podemos concluir isto não apenas pelo que já dissemos sobre o que de comum há entre a escrita destes prefácios e a escrita rosiana em geral, sobre a coerência extrema que habita essa escrita, mas também pelo que o próprio narrador de "Aletria e Hermenêutica" nos diz nos corolários finais desse prólogo, desse pré-logos que é já o logos em todo o seu esplendor poético:

Se viemos do nada, é claro que vamos para o tudo.

Veja-se, vezes, prefácio como todos gratuito.

Ergo:

O livro pode valer pelo muito que nele não deveu caber. (12)

“Aletria e Hermenêutica” é um prefácio “como todos gratuito”. De onde lhe advém este estatuto? Talvez de o prefácio, na verdade, nunca possuir esse estatuto de pré-texto, esse estatuto de inauguração a um tempo do espaço do livro como volume e do tempo do pensamento, da substância do discurso, seja ele poético, filosófico ou científico. O tempo prefacial é afinal outro: os prefácios são os últimos textos a escreverem-se, e, não obstante apresentarem os textos subsequentes e o seu conteúdo conceptual como futuro da enunciação, em formulaçõe como “o que vão ler em seguida...”, etc., eles apresentam como futuro aquilo que já é passado, criando assim o efeito ilusório de absoluta mestria por parte do escritor sobre aquilo que escreve. O que a escrita de Guimarães Rosa pretende deslocar é, com efeito, a ilusão de "presença manifesta” produzida pelo discurso teórico. Nesta ilusão se sustenta a atitude sobranceira de muito discurso teórico-crítico que constitui um dos alvos da linguagem ficcional e da mestria técnica rosiana.

Essa mestria manifesta-se na criação de um corpus de prefácios que, como todos os prefácios, mas de uma forma mais radical, podem ser lidos autonomamente sem verem assim o seu sentido comprometido, ${ }^{15}$ mas que podem também ser lidos, no caso particular de Tutaméia, como quatro estórias mais a acrescentar às restantes que compõem o volume. Também por esta razão é legítimo sustentar que essas peças constituem textos ficcionais,

\footnotetext{
${ }^{15}$ As colectâneas de prefácios que amiúde surgem no mercado editorial configuram uma aceitação velada, por parte da instituição literária, da inexistência do prefácio na sua acepção convencional. Isto é, ao admitir-se a possibilidade de leitura descontextualizada de um texto preambular, é o valor mesmo de presença manifesta que supostamente esse texto ajudaria a criar que se deixa cair.
} 
na medida em que põem em jogo, isto é, ficcionam a ficção que é o estatuto convencional do prefácio, ao mesmo tempo que são peças teóricas que, ao levar por diante esse jogo ficcional, chamam justamente a atenção para a dimensão ficcional que habita toda a teoria. E neste "chamar a atenção" abrem o espaço que permite pensar a ficção enquanto tal, mas também pensá-la na sua relação tangencial com a teoria.

Os prefácios de Tutaméia são quatro narrativas possíveis da impossibilidade da origem, da impossibilidade da hermenêutica enquanto concebida como busca da origem do sentido. Essa impossibilidade é encenada na própria circunstância de os prefácios não serem os primeiros textos no volume a requererem interpretação: neste livro extremamente arquitectónico - mas de uma arquitectónica que ensaia a ruína de toda o desígnio arquitectural -, são os índices e as epígrafes de Schopenhauer que ocupam as duas margens extremas, os limites intersticiais do volume: na verdade, versões invertidas de um texto que é sempre o mesmo e sempre já outro, e talvez também a assunção da impossibilidade de mapear esse espaço inquietante, a obra mesma. Espaço inquietante que assume a dimensão geográfica e metafísica do sertão (pois já em Grande Sertão-Veredas se dizia: “O sertão está em toda a parte”), a obra resta sempre por prefaciar, não obstante a repetição do gesto prefacial.

Tutaméia é pois “um livro maior do que a gente” na medida em que constitui o testamento em que Guimarães Rosa nos lega a sua obra. No momento em que a caneta arrisca no papel os primeiros sulcos, o seu destino é já e desde logo a leitura, o suplemento, a repetição na diferença. Por um lado, este livro propõe-se como uma paródica reformulação do grande Livro da Natureza, o sonho neo-platónico e cabalístico de decifração da escrita de Deus. Mas os prefácios transbordam o livro, e assim subvertem o sonho hermenêutico. São maiores do que o livro, porque falam também da impossibilidade do Livro, da impossibilidade do começo absoluto. Com efeito, eles mostram que todo o começo é sempre já um re-começo, uma prótese no corpo excelso do volume, e uma afirmação da finitude e do adiamento da decifração.

Uma releitura das epígrafes de Schopenhauer que, encimando os índices, marcam as duas extremidades do volume em páginas não numeradas, confirmam esta premência da repetição: "Daí, pois, como já se disse, exigir a primeira leitura paciência, fundada em certeza de que, na segunda, muita coisa, ou tudo, se entenderá sob luz inteiramente outra”. Esta primeira epígrafe funciona a um tempo como advertência e como promessa de sentido, um apelo à releitura aturada. Mas a epígrafe final não altera o teor de promessa e faz pensar sobre até que ponto a promessa foi ou não cumprida: “Já a construção, orgânica e não emendada, do conjunto, terá feito necessário por vezes ler-se duas vezes a mesma passagem”. O grande Livro da Natureza transforma-se assim no livro de areia que a um tempo entretia e atormentava Borges: nas extremidades do volume nunca encontramos um princípio e um fim, apenas a multiplicação abissal das páginas. No entanto, esta dissolução do volume e este adiamento do sentido, isto é, do sentido pleno, não assume para Guimarães Rosa uma dimensão de privação ou de negatividade, constituindo antes a chance do livro como abertura ao futuro. Não por acaso o narrador termina "Aletria e Hermenêutica” com a sentença "O livro pode valer pelo muito que nele não deveu caber" (12). Na impossibilidade de o Livro conter o mundo está a chance do mundo, chance do livro. Sobre outro tema não incide o discurso teórico e preambular dos prefácios de 
Tutaméia, e outro não terá sido o legado, simultaneamente filosófico e literário, da obra de Guimarães Rosa tal como ela se lê a partir destas Terceiras Estórias.

Aqui chegados cumpre recordar que o propósito deste trabalho, que defini no início como simultaneamente heurístico e hermenêutico, era o de aprofundar as questões levantadas pelo jogo rosiano com o conceito convencional de prefácio, na sua articulação com o conceito de livro. Tal propósito levou-nos a considerar a importância do encontro tangencial entre os discursos filosófico e literário, bem como o trânsito - por vezes tão imediato como um piscar de olhos - operado entre o sério das pretensões teóricas e o cómico da sua paródia, mas também do cómico da anedota ao sério da dimensão poética - ou, para recorrer a uma terminologia mais sofística mas nem por isso menos séria, lembrando a citação de Protágoras em “Aletria e Hermenêutica”, da dimensão fármacopoética - da linguagem.

Não nos forneceram respostas estas considerações críticas, e muito menos de tipo definitivo, antes nos trouxeram ao ponto, difícil de mapear, em que a obra de Rosa desagua numa afirmação sem reservas do futuro e do livro como objecto e conceito que, reformulado, pode nomear precariamente esse futuro.

\section{BiBLIOGRAFÍA}

Babo, Maria Augusta. A Escrita do Livro. Lisboa: Vega, 1993.

Blanchot, Maurice. O Livro por Vir. Lisboa: Relógio D’Água, 1984.

Derrida, Jacques. "Hors Livre. Préfaces.” La Dissémination. Paris: Editions du Seuil, 1972.

“This Strange Institution Called Literature.” Acts of Literature. Londres: Routledge, 1992. 33-75.

Martins, José Maria. Guimarães Rosa, O Alquimista do Coração. Petrópolis: Vozes, 1994.

Novis, Vera. Tutaméia: Engenho e Arte. São Paulo: Perspectiva, Editora da USP, 1989. Rosa, João Guimarães. Tutaméia. Terceiras Estórias. Rio de Janeiro: Livraria José Olympio Editora, 1979.

Grande Sertão:Veredas. 32ª Reimpressão. Rio de Janeiro: Editora Nova Fronteira, 1986.

Valente, Luiz. "Fiction and the Reader: The Prefaces of Tutaméia.” Hispanic Review 55/ 3 (1988): 349-62.

Vincent, Jon. João Guimarães Rosa. Twayne’s World Authors Series 506. Boston: Twayne, 1978. 
